\title{
Study of Social Desirability Levels of Female Youth Camp Leader Candidates in Accordance with Some Variables
}

\author{
Bülent Üzümcü \\ Correspondence: Bülent Üzümcü, School of Physical Education and Sport, Gaziantep University, Turkey
}

Received: March 4, 2016 Accepted: March 26, 2016 Online Published: April 13, 2016

doi:10.11114/jets.v4i7.1433

URL: http://dx.doi.org/10.11114/jets.v4i7.1433

\begin{abstract}
The aim of the study examination of the study of social desirability levels of female youth camp leader candiadets in according with some variables. The study the scope of the research consists of 326 female trainees participated in the relevant course of youth camp leader candidates, depending on the Youth and Sport Ministry. As a measurement tool in the research, Akın (2010)'s "Social Desirability Scale" was used. In accordance with the results of the study; a significant difference was found in youth camp leader candidates opinions about social desirability levels towards the education background variable $(\mathrm{F}=5,520, \mathrm{p}=0,001>0,05)$. Another result of the research was that there was not a significant difference in youth camp leader candidates' opinions about social desirability levels towards the profession variable $(\mathrm{F}=1,895, \mathrm{p}=0,060>0,05)$. Towards the scale responses from the participants. According to this result, the scale can be considered to be reliable. Following this, for total points from the scales "Self-Confidence" and "Social Desirability", parametric independent groups t-test, one way variance analysis (ANOVA) and complementary analysis techniques (Tukey if variances were homogeneous, Tamhane's T2 if variances were not homogeneous) were used in the variables showing a normal distribution. The data was resolved in SPSS 22.0 program, the significance levels were regarded as $\mathrm{p}<0,05$.
\end{abstract}

Keywords: camp, leadership, social desirability

\section{Introduction}

A leader is a person who presents common but unclear opinions and desires adopted by group members as appropriate objectives and activates the potential powers of group members towards these objectives. Leadership is a capability of gathering a group of people for certain aims, activating them for achieving these aims and persuading them (Şahin, 2004). Camp leader is of persons with abilities, information and skills who become role models for young people in youth camps, can activate young groups and guide them (http://gsb.gov.tr).

It is possible to mention that high social desirability and confirmation desire slow down current motivation. That is, it is favorable that the relevant motivation is intensive in social desirability and confirmation desire (Sağlam, 2012). Social desirability being a psychological concept was defined as one dimensional structure in originals, but there is not a great theoretical definition (Edwards, 1957).

Social desirability is regarded as tendencies for exaggeration of some behaviors (such as helping someone in difficulty) required and accepted in cultural values, for concealment of non-required behaviors (such as behaving like a patient to escape from fulfilling a duty (Akin, 2010).

Social desirability is that the respondents falsify their responses when showing behaviors in favour of themselves (e.g. giving responses positive for the one when filling in the necessary reports for oneself). Social desirability appears as exaggeration of characteristics or behaviors generally desired and ignorance of ones non-desired. For determining this wrong opinion, one of the methods is to manage the tools measuring social desirability with the tools measuring contents, and to evaluate the effects of social desirability via the correlation analysis (Motl, McAuley \& DiStefano, 2005).

Edwars researched which fields the social desirability concept entered in owing to the ampirical studies. He described the social desirability concept as "the tendency for describing oneself between the social desirability scale values and the non socially required scale values of the person" (Sağlam, 2012). Social desirability shows itself as attribution of positive characteristics to oneself wrongly (deceiving oneself) or rejection of one's own negative characteristics (deceiving others or impression management) (Langdon, Clare \& Murphy, 2010). That is to say, social rejection and 
social desirability mean tendency levels in describing oneself, this is also a very important issue. Discussions about social desirability basically were revealed in the researches about response styles or types in 1960s (Rorer, 1965). Rorer excluded the social desirability concept in his study, (Block, 1965)'s study became effective for showing the power of arguments about social desirability in some situations. The other aspects of social desirability were obtained from these studies (Hartshorne \& May, 1930). Social desirability has an important role in both children and adults at the point of physical activity reports filled with one's explanations (Motl, McAuley \& DiStefano, 2005). This paper presents us selfness which aims to hide faults deliberately or exaggerate positive characteristics. Researches about sport based injuries have suggested that social desirability interaction may cause the ignorance of roles of psychological factors or II Type faults in the sport medicine (Wiechman, Smith, Smoll \& Ptacek, 2010). When people manipulate themselves for certain aims and desires in this way, this gives opportunities for developing ideas about the social desirability structure. Social desirability which is described as the desire for being accepted performing culturally appropriate behaviours, is significant for researchers targeting valid information from questionnaires based on individuals' own explanations. Socially desired response forms based on the desire for socially acceptance or negative approach rejection are benefited in anxiety, struggle and self-respect issues, that is, measurements depending on any person's own explanation (Grossbard, Cumming, Standag, Smith \& Smoll, 2007).

The dimensions of social desirability are 1. Self-Deception, 2. Impression Management. Hereby, in the self-deception method (Paulhus, 1984), self-deception is emphasized to be dealt in two separate characteristics when stating self-deception as one of the two components of social desirability. The first one of these is related with more intense attributions of positive characteristics; the other component is rejection of negative characteristics (that is, self-deceptive, denial). In other words, while a person tells one's success, positive parts of attributes, positive characteristics exaggerating, the one denies or rejects one's unwanted characteristics ignoring them (Sağlam, 2012).

In impression management; it is related how others perceive and evaluate oneself, and known that people generally show tendencies to others about how to create impressions about oneself (Leary, 1996). People manipulate their personal characteristics and behaviors within their efforts for creating certain impressions in environments common for others.

A meta-analysis study indicated that persons who reflected themselves in socially accepted ways in both personal and group practices, had higher points from personality tests rather than persons showing themselves in realistic ways (Akin, 2010:4). Meanwhile, the research results revealed that individuals applied for a job tried to present themselves more positively and as socially accepted ones than they were (Akin, 2010:4). Here, when a relation is in question between individuals' leadership characteristics and social desirability levels, this is significant that individuals' demographical characteristics reflect their social desirability levels. How responses to the questions of the scale used in measuring social desirability reflect the reality is important for the results of the study as well. Instead of showing the reality to questions required in the social desirability scale, persons reflect their opinions to be accepted and confirmed.

\section{Method}

In this research, the scale performed for measuring the social desirability levels of the camp leader candidates and consisted of total 24 items was used. As a measurement tool in the research, Akın (2010)'s "Social Desirability Scale" was used. The scale was complemented in nearly 10-15 minutes. Also, the chosen sampling group was assumed to represent the main group/scope enough and the generalization could be made for the main group from the sample. This study was organized as appropriate for "the comperative relational screening model". Towards the responses to the scale from the participants, the Cronbach Alpha reliability coefficient was estimated to be 0,85 . According to this result, the scale can be said to be quite reliable. The universe of the research consisted of 326 female trainees participated in the course of youth camp leader candidates based on the Ministry of Youth and Sport. The research firstly presented the demographical characteristics, descriptive frequencies and percentage distributions of the participants. Following this, the parametrical independent groups t-test one way variance analysis (ANOVA) and complementary analysis techniques (Tukey if variances were homogenous, Tamhane's T2 if variances were not homogenous) were used in the variables showing a normal distribution for total points from the "Social Desirability" measurements. The data was resolved in the SPSS 22.0 program, the significance was regarded at $p<0,05$.

\section{Findings}

To determine whether there was a significant relation in the social desirability levels of camp leader candidates, the parametrical independent groups t-test one way variance analysis (ANOVA) and complementary analysis techniques (Tukey if variances were homogenous, Tamhane's T2 if variances were not homogenous) were used in the variables showing a normal distribution. 
Table 1. Demographical Characteristics of Youth Camp Leader Candidates

\begin{tabular}{|c|c|c|c|c|}
\hline Age & f & $\%$ & $\mathbf{X}$ & Sd \\
\hline $26-30$ & 326 & 100,0 & 2,0000 & 0,00000 \\
\hline Education & f & $\%$ & $\mathbf{X}$ & Sd \\
\hline High School & 11 & 3,4 & \multirow{4}{*}{2,8221} & \multirow{4}{*}{0,54823} \\
\hline Undergraduate & 50 & 15,3 & & \\
\hline Graduate & 251 & 77,0 & & \\
\hline Master & 14 & 4,3 & & \\
\hline Mother Education & $\mathbf{f}$ & $\%$ & $\mathbf{X}$ & Sd \\
\hline Illiterate & 21 & 6,4 & \multirow{5}{*}{3,4018} & \multirow{5}{*}{1,00209} \\
\hline Literate & 20 & 6,1 & & \\
\hline Primary School & 133 & 40,8 & & \\
\hline Secondary School & 111 & 34,0 & & \\
\hline University & 41 & 12,6 & & \\
\hline Father Education & $\mathbf{f}$ & $\%$ & $\mathbf{X}$ & Sd \\
\hline Illiterate & 3 & 0,9 & \multirow{6}{*}{3,9785} & \multirow{6}{*}{0,85007} \\
\hline Literate & 6 & 1,8 & & \\
\hline Primary School & 77 & 23,6 & & \\
\hline Secondary School & 157 & 48,2 & & \\
\hline University & 75 & 23,0 & & \\
\hline Post-graduate & 8 & 2,5 & & \\
\hline Profession & $\mathbf{f}$ & $\%$ & $\mathbf{X}$ & Sd \\
\hline 1,00 & 18 & 5,5 & \multirow{10}{*}{6,1994} & \multirow{10}{*}{1,92157} \\
\hline 2,00 & 25 & 7,7 & & \\
\hline 3,00 & 1 & 0,3 & & \\
\hline 4,00 & 11 & 3,4 & & \\
\hline 5,00 & 1 & 0,3 & & \\
\hline 6,00 & 2 & 0,6 & & \\
\hline 7,00 & 256 & 78,5 & & \\
\hline 8,00 & 11 & 3,4 & & \\
\hline 9,00 & 1 & 0,3 & & \\
\hline Total & 326 & 100,0 & & \\
\hline
\end{tabular}

Table 2. Distributions of Youth Camp Leader Candidates' Responses to the Question "Do you do sport?"

\begin{tabular}{|c|c|c|c|c|}
\hline & $\mathbf{f}$ & $\%$ & $\mathbf{X}$ & Sd \\
\hline Yes & 219 & 67,2 & 1,3282 & 0,47029 \\
\hline No & 107 & 32,8 & & \\
\hline Total & 326 & 100,0 & & \\
\hline \multicolumn{5}{|c|}{ Table 3. Distributions of Sportive Performance Frequencies of Youth Camp Leader Candidates } \\
\hline & f & $\%$ & $\mathbf{X}$ & Sd \\
\hline Every Day & 52 & 16,0 & 2,7515 & 1,00594 \\
\hline 1 Day in a Week & 59 & 18,1 & & \\
\hline 2 Days in a Week & 133 & 40,8 & & \\
\hline 3 Days in a Week & 82 & 25,2 & & \\
\hline Total & 326 & 100,0 & & \\
\hline \multicolumn{5}{|c|}{ Table 4. Distributions of Factors For Tendencies to Sport in Youth Camp Leader Candidates } \\
\hline & f & $\%$ & $\mathbf{X}$ & Sd \\
\hline On My Own & 289 & 88,7 & 1,1994 & 0,61779 \\
\hline My Family & 17 & 5,2 & & \\
\hline My Friends & 12 & 3,7 & & \\
\hline My Teachers & 8 & 2,5 & & \\
\hline Total & 326 & 100,0 & & \\
\hline
\end{tabular}


Table 5. Distributions of Youth Camp Leader Candidates' Responses to the Question of Determination of Social Desirability Levels

\begin{tabular}{|c|c|c|c|}
\hline & $\mathbf{n}$ & $\mathbf{X}$ & Sd \\
\hline Question 1. I never regret because of my own decisions & 326 & 3,56 & 0,92 \\
\hline Question 2. I do not cerrtainly say something behind one's back & 326 & 3,85 & 0,92 \\
\hline Question 3. I always consider critics about me & 326 & 4,26 & 0,74 \\
\hline $\begin{array}{l}\text { Question 4. When I decide something, other people may seldom change my } \\
\text { opinion }\end{array}$ & 326 & 3,72 & 1,03 \\
\hline Question 5. I think that I can write my fortune & 326 & 3,72 & 1,05 \\
\hline Question 6. I never get things which do not belong to me & 326 & 4,54 & 0,85 \\
\hline Question 7. I rely on my own decisions very much & 326 & 4,02 & 0,76 \\
\hline Question 8. I do not certainly throw rubbish on the street & 326 & 4,42 & 0,79 \\
\hline Question 9. I do not exceed speed limit when using a vehicle & 326 & 4,05 & 1,03 \\
\hline Question 10. I do not consider what other people think about myself & 326 & 2,83 & 1,37 \\
\hline Question 11. I am always honest to myself & 326 & 4,25 & 0,88 \\
\hline Question 12. I always comply with the laws even if I may not be guilty & 326 & 4,21 & 0,82 \\
\hline Question 13. I am exactly a logical person & 326 & 3,86 & 0,90 \\
\hline $\begin{array}{l}\text { Question 14. It is not difficult to keep away from an opinion which strains my } \\
\text { mind }\end{array}$ & 326 & 3,82 & 0,98 \\
\hline Question 15. I do not certainly hide my faults & 326 & 3,90 & 0,87 \\
\hline Question 16. It is not difficult to give up my bad habits & 326 & 4,24 & 0,82 \\
\hline Question 17. My intense feelings do not cause to be prejudiced in my opinions & 326 & 3,90 & 0,94 \\
\hline Question 18. I do not gossip about other people & 326 & 3,94 & 0,94 \\
\hline Question 19. I do not go wrong for my first impression about people & 326 & 3,96 & 0,88 \\
\hline Question 20. Even if I am very compulsory, I never tell a lie & 326 & 3,90 & 0,95 \\
\hline Question 21. I have no bad habits & 326 & 4,27 & 0,94 \\
\hline Question 22. I always take correct steps in my own works & 326 & 3,87 & 0,81 \\
\hline Question 23. I do not certainly swear & 326 & 4,19 & 0,99 \\
\hline Question 24. In shopping I give it back when I take change more & 326 & 4,79 & 0,52 \\
\hline
\end{tabular}
(1,00-Never Disagree, 2,00-Disagree, 3,00-Indecisive, 4,00-Agree, 5,00-Completely Agree)

At Table 5, the rate of ones who said I am indecisive to the question "I do not consider what other people think about myself", was 2.83. Here, most of the research participants were indecisive about what other people think about themselves. The rate of ones who said I completely agree to the question "In shopping I give it back when I take change more", was 4.79.

Table 6. ANOVA Results of Points from Social Desirability Levels Scale to Education Variable

\begin{tabular}{|c|c|c|c|c|c|c|}
\hline Education & $\begin{array}{l}\text { Source } \\
\text { Variance }\end{array}$ & Sum of Squares & sd & Mean Square & $\mathbf{F}$ & $\mathbf{P}$ \\
\hline & Between-Groups & 1951,248 & 3 & 650,416 & 5,520 & 0,001 \\
\hline & In-Groups & 37944,130 & 322 & 117,839 & & \\
\hline & Total & 39895,377 & 325 & & & \\
\hline
\end{tabular}

$\mathbf{p}<\overline{\mathbf{0 , 0 5}}$

In accordance with Table 6, a significant difference was found in the opinions of social desirability levels in the youth camp leader candidates to the education variable $(\mathrm{F}=5,520, \mathrm{p}=0,001>0,05)$. To find which trial groups differences resulted from, the Tukey test was performed. As a result of the test, there was a significant difference in favour of the youth camp leader candidates having undergraduate and graduate education rather than the youth camp leader candidates having high school education. The test results were given at Table 7. 
Table 7. Results of Tukey Test to Find in Which Trial Groups Points from Social Desirability Levels Scale to Education Variable Differed

\begin{tabular}{|c|c|c|c|c|c|}
\hline & $\begin{array}{l}\text { Grups (I) } \\
\text { Father Education }\end{array}$ & $\begin{array}{l}\text { Grups }(\mathbf{J}) \\
\text { Father Education }\end{array}$ & $\bar{x}_{i}-\bar{x}_{j}$ & sd & D \\
\hline \multirow{12}{*}{ Tukey HSD } & \multirow{3}{*}{ High Shool } & Undergraduate & $-12,11818^{*}$ & 3,61516 & 0,005 \\
\hline & & Graduate & $-11,45165^{*}$ & 3,34397 & 0,004 \\
\hline & & Master & $-4,96104$ & 4,37375 & 0,669 \\
\hline & \multirow{3}{*}{ Undergraduate } & High Shool & $12,11818^{*}$ & 3,61516 & 0,005 \\
\hline & & Graduate & 66653 & 1,68115 & 0,979 \\
\hline & & Master & 7,15714 & 3,28235 & 0,131 \\
\hline & \multirow{3}{*}{ Graduate } & High Shool & $11,45165^{*}$ & 3,34397 & 0,004 \\
\hline & & Undergraduate &,- 66653 & 1,68115 & 0,979 \\
\hline & & Master & 6,49061 & 2,98103 & 0,132 \\
\hline & \multirow{3}{*}{ Master } & High Shool & 4,96104 & 4,37375 & 0,669 \\
\hline & & Undergraduate & $-7,15714$ & 3,28235 & 0,131 \\
\hline & & Graduate & $-6,49061$ & 2,98103 & 0,132 \\
\hline
\end{tabular}

Table 8. ANOVA Results of Points from Social Desirability Levels Scale to Mother Education Variable

\begin{tabular}{lllccccc}
\hline Education & $\begin{array}{l}\text { Source } \\
\text { Variance }\end{array}$ & $\begin{array}{l}\text { Sum } \\
\text { Squares }\end{array}$ & of & sd & Mean Square & F & P \\
\hline & Between-Groups & 401,444 & 4 & 100,361 & 0,816 & 0,516 \\
\cline { 2 - 7 } & In-Groups & 39493,934 & 321 & 123,034 & & \\
\cline { 2 - 6 } & Total & 39895,377 & 325 & & & \\
\hline
\end{tabular}

$\mathbf{p}<\mathbf{0 , 0 5}$

In accordance with Table 8, a significant difference was not found in the opinions of social desirability levels in the youth camp leader candidates to the mother education variable $(\mathrm{F}=0,816, \mathrm{p}=0,516>0,05)$.

Table 9. ANOVA Results of Points from Social Desirability Levels Scale to Father Education Variable

\begin{tabular}{|c|c|c|c|c|c|c|}
\hline Education & $\begin{array}{l}\text { Source } \\
\text { Variance }\end{array}$ & $\begin{array}{ll}\text { Sum } & \text { of } \\
\text { Squares } & \end{array}$ & sd & Mean Square & $\mathbf{F}$ & $\mathbf{P}$ \\
\hline & Between-Groups & 681,420 & 5 & 136,284 & 1,112 & 0,354 \\
\hline & In-Groups & 39213,957 & 320 & 122,544 & & \\
\hline & Total & 39895,377 & 325 & & & \\
\hline
\end{tabular}

$\mathbf{p}<\mathbf{0 , 0 5}$

In accordance with Table 9, a significant difference was not also found in the opinions of social desirability levels in the youth camp leader candidates to the father education variable $(\mathrm{F}=1,112, \mathrm{p}=0,354>0,05)$.

Table 10. ANOVA Results of Points from Social Desirability Levels Scale to Profession Variable

\begin{tabular}{lllccccc}
\hline Education & $\begin{array}{l}\text { Source } \\
\text { Variance }\end{array}$ & $\begin{array}{l}\text { Sum } \\
\text { Squares }\end{array}$ & of & sd & Mean Square & F & p \\
\hline & Between-Groups & 1821,140 & 8 & 227,643 & 1,895 & 0,060 \\
\cline { 2 - 7 } & In-Groups & 38074,237 & 317 & 120,108 & & \\
\cline { 2 - 6 } & Total & 39895,377 & 325 & & & \\
\hline
\end{tabular}

$\mathbf{p}<\mathbf{0 , 0 5}$

At Table 10, there was not a significant difference in the opinions of social desirability levels in the youth camp leader candidates to the profession variable $(\mathrm{F}=1,895, \mathrm{p}=0,060>0,05)$.

Table 11. T-Test Results of Points from Social Desirability Levels Scale to Sportive Performance Variable

\begin{tabular}{llllll}
\hline Sportive Performance & N & Average & sd & T & p \\
\hline Yes & 219 & 96,2283 & 11,33530 & 0,367 & 0,714 \\
\hline No & 107 & 95,7477 & 10,58131 & & \\
\hline
\end{tabular}

$\mathbf{p}<\overline{\mathbf{0 , 0 5}}$

At Table 11, there was not also a significant difference in the opinions of social desirability levels in the youth camp leader candidates to the sportive performance variable $(t=0,367, \mathrm{p}=0,714>0,05)$ 
Table 12. ANOVA Results of Points from Social Desirability Levels Scale to Sportive Performance Frequency Variable

\begin{tabular}{|c|c|c|c|c|c|c|}
\hline Educaion & $\begin{array}{l}\text { Source of } \\
\text { Variance }\end{array}$ & $\begin{array}{l}\text { Sum of } \\
\text { Squares }\end{array}$ & sd & Mean Square & $\mathbf{F}$ & $\mathbf{p}$ \\
\hline & Between-Groups & 266,276 & 3 & 88,759 & 0,721 & 0,540 \\
\hline & In-Groups & 39629,101 & 322 & 123,072 & & \\
\hline & Total & 39895,377 & 325 & & & \\
\hline
\end{tabular}

$\mathbf{p}<0, \overline{05}$

Looking at Table 12, any significant difference was not observed in the opinions of social desirability levels in the youth camp leader candidates to the sportive performance frequency $(\mathrm{F}=0,721, \mathrm{p}=0,540>0,05)$.

Table 13. ANOVA Results of Points from Social Desirability Levels Scale to Factors for Sportive Tendencies

\begin{tabular}{|c|c|c|c|c|c|c|}
\hline Education & $\begin{array}{ll}\text { Source } & \text { of } \\
\text { Variance } & \end{array}$ & $\begin{array}{l}\text { Sum } \\
\text { Squares }\end{array}$ & sd & Mean Square & $\mathbf{F}$ & $\mathbf{p}$ \\
\hline & Between-Groups & 292,631 & 3 & 97,544 & 0,793 & 0,498 \\
\hline & In-Groups & 39602,747 & 322 & 122,990 & & \\
\hline & Total & 39895,377 & 325 & & & \\
\hline
\end{tabular}

$\mathbf{p}<\mathbf{0 , 0 5}$

At Table 13, any significant difference was not also observed in the opinions of social desirability levels in the youth camp leader candidates to the factors for sportive tendencies $(\mathrm{F}=0,793, \mathrm{p}=0,498>0,05)$.

\section{Discussion and Results}

In this study, the social desirability concept which is one of the most important problems of the self-declaration method significant for social science, has been analysed. Total 326 participant females were supported as the leader candidates of youth camps herein, so the $100 \%$ relevant participants of the study consisted of females.

The potential effects of social desirability have been known in social psychology branches for long years. Its negative effects have appeared in both theoretical levels and practice levels (Alp, 2012).

In spite of generally accepted importance of social desirability, it is possible to mention about a number of unsolved problems. Firstly, there are some discussions about what are problems. Given how social desirability was a problem for self-declaration in fact, many researchers suggested their opinions and most of them thought that the problems were exaggerated. For example, (Diener, 1984) and (McCrae, 1986) stated social desirability played an important role in being subjectively good. Any person seemed to have higher social desirability to be self-accepted and feel better. Krosnick (1999) suggested that social desirability was overdone in voting behavior reports, it did not actually have rates as expected.

Social desirability means response tendencies for seeming well in the report types filled by individuals instead of answering correctly and honestly. For instance, people have such tendencies that they show behaviors such as religional services with social necessities (Hadaway, Marler \& Chaves, 1993) and voting (Silver, Anderson \& Abramson, 1986) more than they are, such as non socially wanted drug addiction (Mensch \& Kendel, 1988), bankruptcy (Locander, Sudman \& Bradburn, 1976) less than they are or like they are not available.

Any high relation was not observed in the best known measurements of social desirability (for example, Crowne \& Marlowe, 1960; Edwards, 1231957), this was supported by researchers' different definitions about social desirability. Social desirability is a potential problem for behavior researches, because people have tendencies to hide non socially desired behaviors less or more and to response in socially desired ways (Gucciardi, Jalleh \& Donovan, 2010).

In our paper, originality was not directly dealt as an effective factor in describing social desirability, any negative relation was not a matter of subject, that's why, it is necessary to analyse it in more detailed perspectives positively and negatively.

The following result items can be observable:

Looking at Table 6, a significant difference was found in the opinions of the youth camp leader candidates about the social desirability levels in accordance with the education variable $(F=5,520, p=0,001>0,05)$. As a result of the test; there was a significant difference in favour of the youth camp leader candidates having undergraduate and graduate education rather than ones having high school education. The test results were given at Table 7.

Looking at Table 8, a significant difference was not found in the opinions of the youth camp leader candidates about the social desirability levels in accordance with the mother education variable $\quad(\mathrm{F}=0,816, \mathrm{p}=0,516>0,05)$.

* Looking at Table 9, there was not a significant difference in the opinions of youth camp leader candidates about the social desirability levels in accordance with the father education variable $(\mathrm{F}=1,112, \mathrm{p}=0,354>0,05)$. 
* At Table 10, no significant difference appeared in the opinions of youth camp leader candidates about the social desirability levels in accordance with the profession variable $(\mathrm{F}=1,895, \mathrm{p}=0,060>0,05)$.

* At Table 11, no significant difference also appeared in the opinions of youth camp leader candidates about the social desirability levels in accordance with the sportive performance variable ( $t=0,367, p=0,714>0,05)$.

* At Table 12, there was not any significant difference in the opinions of youth camp leader candidates about the social desirability levels in accordance with the sportive performance frequency variable $(\mathrm{F}=0,721$, $\mathrm{p}=0,540>0,05$ ).

* At Table 13, there was not any significant difference in in the opinions of youth camp leader candidates about the social desirability levels in accordance with the factor of tendency for sport $(F=0,793, p=0,498>0,05)$.

As a result of comparisons in the youth camp leader candidates participated in the research, only a significant relation was found between the social desirability and the education levels. Also, any significant differences were not found in the social desirability levels and mother education, father education, profession variable, sportive performance, sportive performance frequency and factors for sportive tendencies of the research participants.

Experimental studies are very limited about anxiety and social desirability but the results from these studies are in harmony (Stöber \& Wolfradt, 2001). Increasing similar studies about the field of social desirability in literature has a great importance for having comparable results.

\section{Recommendations}

Within our research, the recommendations about this issue are as follows;

1. Since there were not non-similar studies in our research for comparisons, it was difficult to compare all results of the study. In this regard, the study must be repetitive.

2. It is important to reveal various results when doing these types of studies in different fields.

3. When choosing the sampling group, the meaning levels of questions in the measurements must be considered to be at an appropriate level not to ignore meaningful differences.

4. In delicate researches social desirability is observed more intensively, the participants can be informed about the research topic after having data.

5. By enlarging the sampling group, the research can be compared with a lot of and different variables.

\section{References}

Akın, A. (2010). İki boyutlu sosyal istenirlik ölçeğinin geliştirilmesi ve psikometrik özelliklerinin araştırllması. Gazi Üniversitesi Ĕgitim Fakültesi Dergisi, 30(3), 4-771-784.

Alp, Z. (2012). Çalışanların ve emeklilerin sosyal istenirlik ve öz-duyarlık açısından karşılaştırılma. Maltepe Üniversitesi Sosyal Bilimler Enstitüsü Psikoloji Anabilim Dalı Endüstri ve Örgüt Psikolojisi, Yayınlanmamış Yüksek Lisans Tezi, s.10-19, İstanbul.

Block, J. (1965). The challenge of response sets: Unconfounding meaning, acquiescence, and social desirability in the MMPI. New York: Appleton-Century-Crofts.

Crowne, D. P., \& Marlowe, D. (1960). A new scale of social desirability independent of psychopathology, 24, 349-354.

Diener, E. (1984). Subjective well-being. Psychological Bulletin, 95, 542-575. http://dx.doi.org/10.1037/0033-2909.95.3.542

Edwards, A. L. (1957). The social desirability variable in personality assessment and research. New York: Dryden, pp.6.

Grossbard, J. R., Cumming, S. P., Standag, M., Smıth, R. E., \& Smoll, F. L. (2007). Social desirability and relations between goal orientations and competitive trait anxiety in young athletes. Psychology of Sport and Exercise, 8, 491-505. http://dx.doi.org/10.1016/j.psychsport.2006.07.009

Gucciardi, D. F., Jalleh, G., \& Donovan, R. J. (2010). Does social desirability influence the relationship between doping attitudes and doping susceptibility in athletes? Psychology of Sport and Exercise, 11, 479-486. http://dx.doi.org/10.1016/j.psychsport.2010.06.002

Hadaway, C. K., Marler, P. L., \& Chaves, M. (1993). What the polls don't show: A closer look at U.S. church attendance. American Sociological Review, 58, 741-752. http://dx.doi.org/10.2307/2095948

Hartshorne, H., \& May, H. A. (1930). Studies in the nature of character. New York: MacMillan. 
Langdon, P. E., Clare, I. C. H., \& Murphy, G. H. (2010). Measuring social desirability amongst men with intellectual disabilities: The psychometric properties of the Self- and Other-Deception Questionnaire-Intellectual Disabilities. Research in Developmental Disabilities, 31, 1601-1608. http://dx.doi.org/10.1016/j.ridd.2010.05.001

Leary, M. R. (1996). Self Presentation-Impression Management and Interpersonal Behaviour. Boulder, CO: Westview.

Locander, W. B., Sudman, S., \& Bradburn, N. (1976). An investigation of interview method, threat and response distortion. Journal of the American Statistical Association, 71, 269-275. http://dx.doi.org/10.1080/01621459.1976.10480332

McCrae, R. R. (1986). Well being scales do not measure social desirability, Journal of Gerontology, 41, 390-392. http://dx.doi.org/10.1093/geronj/41.3.390

Mensch, B. S., \& Kendel, D. B. (1988). Underreporting of substance use in a national longitudinal youth cohort: Individual and interviewer effects. Public Opinion Quarterly, 52, 100-124. http://dx.doi.org/10.1086/269084

Motl, R. W., Mcauley, E., \& Distefano, C. (2005). Is social desirability associated with self-reported physical activity? Preventive Medicine, 40, 735-739. http://dx.doi.org/10.1016/j.ypmed.2004.09.016

Paulhus, D. L. (1984). Two-component models of socially desirable responding, Journal of Personality and Social Psychology, 46, 598-609. http://dx.doi.org/10.1037/0022-3514.46.3.598

Rorer, L.G. (1965). The great response-style myth, Psychological Bulletin, 63, 129-156. http://dx.doi.org/10.1037/h0021888

Sağlam, A. (2012). Çalışanların ve yöneticilerin sosyal istenirlik ve özgünlük düzeylerinin karşılaştırılması. Maltepe Üniversitesi Sosyal Bilimler Enstitüsü Psikoloji Anabilim Dalı Endüstri ve Örgüt Psikolojisi, Yayınlanmamış Yüksek Lisans Tezi, s.10-50, İstanbul.

Şahin, H. M. (2004). Beden eğitimi ve sporda temel kavramlar sözlügü, nobel yayın dağıtım, geliştirilmiş 2. bask1, Ankara.

Silver, D. B., Anderson, B. A., \& Abramson, P. R. (1986). Who overeports voting? American Political Science Review, 80, 613-624. http://dx.doi.org/10.2307/1958277

Stöber, J., \& Wolfradt, U. (2001). Worry and social desirability: opposite relationships for socio-political and social-evaluation worries. Personality and Individual Differences, 31, 605-613. http://dx.doi.org/10.1016/S0191-8869(00)00165-3

Wiechman, S. A., Smith, R. E., Smoll, F. L., \& Ptacek, J. T. (2000). Masking effects of social desirability response set on relations between psychosocial factors and sport injuries: A methodological note. Journal of Science and Medicine in Sport, 3(2), 194-202. http://dx.doi.org/10.1016/S1440-2440(00)80081-X

This work is licensed under a Creative Commons Attribution 3.0 License. 